\title{
Voortijdige schoolverlaters
}

Citation for published version (APA):

Huijgen, T. G., Meng, C. M., \& Verhagen, A. M. C. (2012). Voortijdige schoolverlaters. ROA. ROA Fact Sheets No. 002 https://doi.org/10.26481/umarof.2012002

Document status and date:

Published: 01/01/2012

DOI:

10.26481/umarof.2012002

Document Version:

Publisher's PDF, also known as Version of record

\section{Please check the document version of this publication:}

- A submitted manuscript is the version of the article upon submission and before peer-review. There can be important differences between the submitted version and the official published version of record.

People interested in the research are advised to contact the author for the final version of the publication, or visit the DOI to the publisher's website.

- The final author version and the galley proof are versions of the publication after peer review.

- The final published version features the final layout of the paper including the volume, issue and page numbers.

Link to publication

\footnotetext{
General rights rights.

- You may freely distribute the URL identifying the publication in the public portal. please follow below link for the End User Agreement:

www.umlib.nl/taverne-license

Take down policy

If you believe that this document breaches copyright please contact us at:

repository@maastrichtuniversity.nl

providing details and we will investigate your claim.
}

Copyright and moral rights for the publications made accessible in the public portal are retained by the authors and/or other copyright owners and it is a condition of accessing publications that users recognise and abide by the legal requirements associated with these

- Users may download and print one copy of any publication from the public portal for the purpose of private study or research.

- You may not further distribute the material or use it for any profit-making activity or commercial gain

If the publication is distributed under the terms of Article $25 \mathrm{fa}$ of the Dutch Copyright Act, indicated by the "Taverne" license above, 
Tuastricht University in Learning!

Research Centre for Education and the Labour Market | ROA

\section{Voortijdige schoolverlaters}

\section{ROA Fact Sheet}

ROA-F-2012/2

Researchcentrum voor Onderwijs en Arbeidsmarkt | ROA Research Centre For Education and the Labour Market / ROA 


\section{Inleiding}

Welke redenen noemen voortijdige schoolverlaters (vsv'ers) voor hun voortijdige uitval? Wat waren vroege signalen? Zijn vsv'ers vaker gepest dan hun studiegenoten die het diploma wel hebben behaald? Wat is de huidige bezigheid van de vsv'ers; zijn ze weer terug in het onderwijs gekeerd, aan het werk of geen van beide? En hebben ze achteraf gezien spijt van hun beslissing om voortijdig te stoppen?

Om een antwoord op deze vragen te kunnen geven zijn in het najaar van $201 \mathrm{I}$ vragenlijsten afgenomen onder 2.I45 ongediplomeerde vsv'ers. Dit zijn leerlingen die in het schooljaar 2009/20IO zonder diploma hun opleiding in het voortgezet onderwijs (VMBO, HAVO of VWO) of in het $\mathrm{MBO}$ hebben verlaten zonder in het bezit te zijn van een startkwalificatie.

Deze enquête onder ongediplomeerde schoolverlaters maakt deel uit van de jaarlijkse schoolverlatersenquêtes van het Researchcentrum voor Onderwijs en Arbeidsmarkt (ROA). De schoolverlatersonderzoeken worden al sinds het begin van de jaren '9o door het ROA uitgevoerd. Voor een aantal onderdelen komen de vragen op de ongediplomeerde en gediplomeerde vragenlijsten overeen zodat vergelijkingen tussen beide groepen op een aantal belangrijke indicatoren mogelijk zijn. Gediplomeerden zijn in dit verband schoolverlaters die hun opleiding met een diploma verlaten, ongeacht of dit wel of niet een startkwalificatie is.

\section{Achtergrondkenmerken respondenten}

Om een beeld te geven van de samenstelling van de gegevens worden hieronder enkele achtergrondkenmerken van de respondenten beschreven. Zie voor een uitgebreid overzicht van de achtergrondkenmerken per opleidingsniveau tabel $\mathrm{B}$ i in de bijlagen.

De in dit factsheet omschreven groep ongediplomeerde voortijdige schoolverlaters is niet gelijk aan de totale groep voortijdig schoolverlaters zoals die landelijk worden gedefinieerd. Omdat de focus ligt op de redenen voor het stoppen met een opleiding zijn de personen die wel een diploma hebben behaald maar geen startkwalificatie hebben niet in de steekproef opgenomen. Aangezien deze personen feitelijk hun opleiding niet hebben afgebroken kan er ook niet naar de redenen voor het afbreken van de opleiding worden gevraagd. De hier omschreven achtergrondkenmerken kunnen dus afwijken van de achtergrondkenmerken van de totale populatie vsv'ers in Nederland.

\section{Opleidingsniveau}

Van de respondenten volgde één op de tien in het schooljaar 2009/20Io een opleiding op HAVO of VWO niveau, ongeveer twee op de tien volgde een opleiding op VMBO niveau en de rest volgde een opleiding op MBO niveau.

\section{Leeftijd en geslacht}

De onderzochte vsv'ers zijn gemiddeld 19 jaar oud en iets meer dan de helft van de respondenten is vrouw. Bij de respondenten afkomstig uit het $\mathrm{MBO}$ niveau 3/4 ligt het percentage vrouwen vrij hoog $(60 \%)$, terwijl het bij de respondenten uit het $\mathrm{VMBO}$ wat lager ligt (40\%).

\section{Etniciteit}

Drie van de vier vsv-respondenten zijn autochtoon. Toch ligt dit percentage iets lager dan onder de gediplomeerde respondenten: $83 \%$ van de gediplomeerde respondenten is autochtoon. Op het VMBO en MBO niveau $\mathrm{I} / 2$ is er tevens een relatief grote groep vsv-respondenten die niet-westers allochtoon is (I8\% c.q. $20 \%$ ).

\section{Gezinssamenstelling en kinderen}

Bijna de helft van de vsv-respondenten komt uit een tweeouder gezin, terwijl dit onder de gediplomeerden $8 \mathrm{I} \%$ is. Van de onderzochte vsv'ers uit MBO niveau 3/4 woont 2I\% zelfstandig. Dit is een vrij hoog percentage vergeleken met het totaal van de vsv-respondenten (I4\% woont zelfstandig). De vsv'ers afkomstig uit het $\mathrm{MBO}$ geven relatief het vaakst aan dat ze een kind hebben ( $14 \%$ van de vsv'ers uit $\mathrm{MBO}$ niveau $\mathrm{I} / 2$ en $7 \%$ van de vsv'ers uit MBO niveau $3 / 4$ ). Het zijn met name vrouwen die vanwege kinderen hun opleiding niet afmaken: van de respondenten met een kind is $89 \%$ vrouw.

De onderzochte vsv'ers afkomstig uit een HAVO/VWO opleiding geven het vaakst aan uit een tweeouder gezin te komen, geen kinderen te hebben en (bijna) altijd Nederlands te spreken met hun ouders. Ook zijn hun ouders het vaakst hoger opgeleid (HBO/WO). Onderzochte vsv'ers die zijn gestopt met een opleiding op $\mathrm{MBO}$ niveau $\mathrm{I} / 2$ geven het minst vaak aan uit een tweeouder gezin te komen en thuis (bijna) altijd Nederlands te spreken. Ook geven zij het vaakst aan dat ze een kind hebben en dat hun ouders laag opgeleid zijn (MAVO, VBO of VMBO).

\section{Belangrijkste redenen om te stoppen}

Aan de vsv'ers zijn I9 mogelijke redenen voorgelegd waarbij ze konden aangeven in welke mate iedere reden een rol heeft gespeeld bij hun beslissing om voortijdig te stoppen met hun opleiding. Vervolgens is hen gevraagd welke van deze redenen voor hen de belangrijkste reden voor hun voortijdige uitval is geweest. In figuur I zijn deze belangrijkste redenen voor voortijdige uitval geclusterd weergegeven, gesorteerd naar opleidingsniveau. Zie voor een volledige lijst van de belangrijkste redenen tabel $\mathrm{B}_{2}$ in de bijlagen. 
Figuur 1

Belangrijkste reden voortijdige uitval, per opleidingsniveau

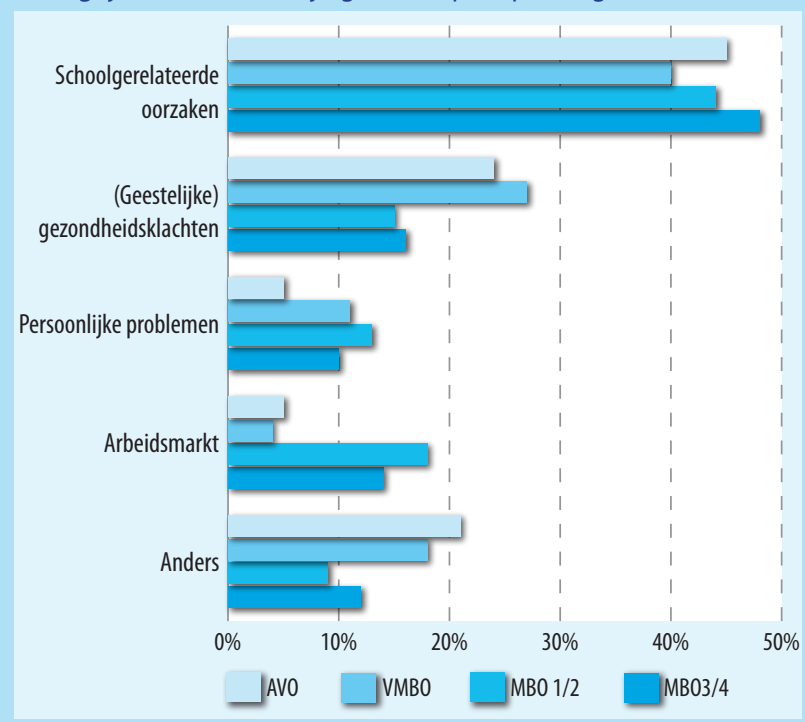

Schoolgerelateerde oorzaken worden in totaal het vaakst genoemd als belangrijkste oorzaak voor voortijdige uitval (45\%). Op nummer twee van de meest genoemde belangrijkste oorzaken van voortijdige uitval staan de (geestelijke) gezondheidsklachten (I8\%). De meest genoemde redenen voor voortijdige uitval zijn hiermee vergelijkbaar met die van de afgelopen twee jaren.

In figuur $\mathrm{I}$ is te zien dat vsv'ers van alle onderwijsniveaus aangeven dat een aan school gerelateerde oorzaak de belangrijkste reden is geweest voor hun voortijdige uitval. De meest genoemde redenen die hieronder vallen zijn "de opleiding was inhoudelijk (toch) niet wat ik wilde", "de opleiding was slecht georganiseerd" en "de opleiding was te moeilijk en/of gezakt voor het eindexamen”. Vsv'ers afkomstig uit MBO niveau 3/4 noemen schoolgerelateerde oorzaken vergeleken met vsv'ers uit andere opleidingsniveaus het vaakst (48\%). Zowel bij de mannelijke als bij de vrouwelijke vsv'ers worden schoolgerelateerde oorzaken het vaakst genoemd als belangrijkste reden. Hetzelfde geldt voor autochtone en allochtone vsv'ers. Hieruit valt op te maken dat geslacht of etniciteit geen rol speelt bij het noemen van schoolgerelateerde oorzaken als belangrijkste reden voor voortijdige uitval.

(Geestelijke) gezondheidsklachten worden vaker door HAVO/VWO-ers (24\%) en VMBO-ers (27\%) dan door MBO-ers (niveau I/2: $15 \%$ en niveau 3/4: $16 \%$ ) als belangrijkste reden voor voortijdige uitval genoemd. Deze hoofdcategorie bestaat voor de helft uit vsv'ers die "psychische problemen" als belangrijkste reden hebben genoemd. Ook "ziekte" is een veel genoemde reden die onder deze categorie valt. Van de vsv'ers die (geestelijke) gezondheidsklachten als belangrijkste reden noemen is de meerderheid vrouw (6I\%). Het percentage allochtonen en autochtonen is vergelijkbaar met die in de steekproef, wat betekent dat etniciteit geen rol lijkt te spelen bij het noemen van (geestelijke) gezondheidsklachten als belangrijkste reden.
De arbeidsmarkt wordt relatief vaker als belangrijkste reden voor voortijdige uitval genoemd door MBO-ers (niveau I/2: $18 \%$ en niveau 3/4: $14 \%$ ) dan door HAVO/ VWO-ers (5\%) en VMBO-ers (4\%). Dat is niet geheel verwonderlijk, aangezien $\mathrm{MBO}$-ers in een leerwerkplek/ stage al in aanraking komen met de arbeidsmarkt en zodoende waarschijnlijk meer bloot worden gesteld aan de 'pull factor'. Ook bij jongens en allochtonen (westers en niet-westers) wordt de arbeidsmarkt wat vaker als de belangrijkste reden voor voortijdige uitval genoemd.

Figuur 2 geeft weer of er samenhang is tussen de redenen waarvan wordt aangegeven dat ze een (heel) belangrijke rol hebben gespeeld bij de beslissing om voortijdig te stoppen met de opleiding ('(heel) belangrijke rol'), en de redenen die de doorslag hebben gegeven bij de beslissing ('belangrijkste reden'). De punten in de grafiek geven de 19 redenen voor voortijdige uitval weer. Hoe verder een punt (horizontaal) verwijderd is van de diagonale stippellijn, hoe meer vsv'ers die reden wel als (heel) belangrijke rol, maar niet als de doorslaggevende reden hebben genoemd. Dat de punten, naarmate je verder naar rechts gaat op de $\mathrm{x}$-as, steeds verder van de stippellijn verwijderd zijn, geeft aan dat veel vsv'ers meerdere redenen als (heel) belangrijk bij hun beslissing hebben genoemd.

Figuur 2

Belangrijke rol versus belangrijkste reden voortijdige uitval

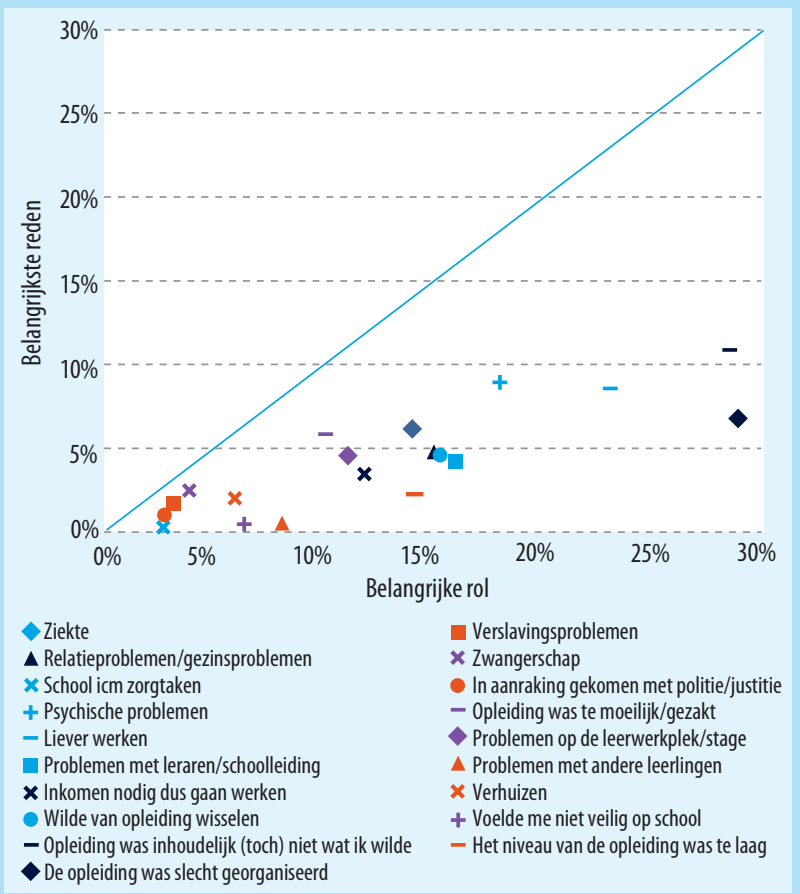

Links onderin de figuur is een puntencluster te zien. Dit zijn redenen waarvan relatief weinig vsv'ers aangeven dat het een (heel) belangrijke rol heeft gespeeld bij hun beslissing om voortijdig te stoppen, maar waarbij diegenen die het wel als (heel) belangrijke rol noemen het doorgaans ook als belangrijkste reden wordt genoemd. Zo zijn er relatief weinig vsv'ers waarbij verslavingsproblemen een (heel) belangrijke rol spelen ( $\square)$, maar bij diegenen waar versla- 
vingsproblemen een rol spelen is het vaak ook meteen de belangrijkste reden voor hun voortijdige uitval.

Aan de rechterkant van de grafiek zijn een aantal punten te zien die vrij ver van de diagonale stippellijn af staan. De reden 'de opleiding was slecht georganiseerd' $(\checkmark)$ is het verst van de stippellijn verwijderd. Dit betekent dat er relatief veel vsv'ers zijn waarbij de slechte organisatie van de opleiding een (heel) belangrijke rol heeft gespeeld bij hun beslissing om voortijdig te stoppen, maar dat er relatief weinig vsv'ers zijn waarbij het ook de doorslag heeft gegeven bij hun beslissing (belangrijkste reden). Hetzelfde geldt voor vsv'ers die een verkeerde opleidingskeuze hebben gemaakt ('opleiding was (inhoudelijk) toch niet wat ik wilde'), die liever gingen werken of die psychische problemen hadden. Er zijn relatief veel vsv'ers waar psychische problemen een (heel) belangrijke rol speelde bij de beslissing, maar bij lang niet al deze vsv'ers gaven de psychische problemen ook de doorslag bij de beslissing.

\subsection{Vroege signalen bij uitval}

Aan de vsv'ers is gevraagd of ze tijdens de opleiding wel eens hebben gespijbeld en zo ja, hoe vaak en waarom. Uit de resultaten blijkt dat $60 \%$ van de vsv'ers wel eens heeft gespijbeld, waarvan een derde (34\%) één of twee keer per week of (bijna) dagelijks spijbelde. Dit is een toename van het percentage spijbelaars ten opzichte van het vorige meetjaar (20I0). Toen gaf $52 \%$ aan wel eens te spijbelen. Binnen de groep spijbelaars is de frequentie van het spijbelen wel vergelijkbaar met de vorige meting. Van de vsv'ers afkomstig uit het $\mathrm{MBO}$ heeft meer dan de helft (niveau I/2: $59 \%$ en niveau 3/4: 70\%) wel eens gespijbeld. Van de vsv'ers uit het VO heeft iets minder dan de helft ( $48 \%$ van de HAVO/VWO-ers en $44 \%$ van de VMBO-ers) wel eens gespijbeld. De toename van het percentage spijbelaars hoeft overigens niet te betekenen dat er vaker wordt gespijbeld. Door alle (beleids)maatregelen is het aantal vsv'ers de afgelopen jaren gedaald, waardoor steeds meer de 'harde kern' overblijft. Tabel I geeft de redenen om te spijbelen weer in vijf hoofdcategorieën, uitgesplitst naar het opleidingsniveau van de spijbelende vsv'ers. Zie voor de volledige lijst met spijbelredenen tabel $\mathrm{B}_{3}$ in de bijlagen.

In tabel $\mathrm{I}$ is te zien dat een aan school gerelateerde oorzaak in totaal het vaakst wordt genoemd als spijbelreden (49\%). De meest genoemde spijbelredenen die onder deze categorie vallen zijn "omdat sommige lessen niet interessant waren" en "omdat de hele opleiding niet interessant was". Vsv'ers uit alle opleidingsniveaus noemen schoolgerelateerde oorzaken het vaakst als spijbelreden. Bij de vsv'ers uit $\mathrm{MBO}$ niveau $3 / 4$ is er zelfs een meerderheid (58\%) die dit als spijbelreden heeft genoemd.

(Geestelijke) gezondheidsklachten zijn met name spijbelredenen voor $\mathrm{HAVO} / \mathrm{VWO}$-ers $(22 \%)$ en VMBO-ers $(24 \%)$. Deze categorie bestaat voor het grootste deel uit vsv'ers die "omdat ik te moe was" als spijbelreden noemden. Ook is er een aantal vsv'ers dat "psychische problemen" als spijbelreden heeft genoemd.
Relatief weinig vsv'ers spijbelen vanwege persoonlijke problemen (4\%). Binnen deze categorie wordt een problematische thuissituatie het vaakst genoemd als spijbelreden. De aantrekkingskracht van de arbeidsmarkt is met name bij de vsv'ers uit MBO niveau I/2 een belangrijke reden geweest om te spijbelen ( $\mathrm{I} 3 \%)$. Het is niet verwonderlijk dat $\mathrm{MBO}$-ers het vaakst spijbelen vanwege de aantrekkingskracht van de arbeidsmarkt, omdat zij daar vanwege hun studie het meest mee in aanraking komen.

Ten slotte zijn er vrij veel vsv'ers die aangeven dat er een 'andere' reden is geweest om te spijbelen (22\%). Dit geeft aan dat de redenen van spijbelen vaak heel divers zijn en per persoon verschillen.

Spijbelen kan een vroeg signaal van voortijdige uitval zijn. Dit is vooral aannemelijk wanneer een bepaalde factor zowel de spijbelreden als de belangrijkste reden van voortijdige uitval is. Uit tabel 2 blijkt dat de reden om te spijbelen vaak overeenkomt met de belangrijkste reden voor voortijdige uitval. Dit is te zien in de gearceerde velden, die de hoogste percentages in de rijen weergeven.

Een ruime meerderheid van de vsv'ers die 'schoolgerelateerde oorzaken' als spijbelreden heeft genoemd (60\%) heeft 'schoolgerelateerde oorzaken' ook als belangrijkste reden van voortijdige uitval genoemd. De helft van de vsv'ers die 'persoonlijke problemen' als spijbelreden noemt (50\%), noemt 'persoonlijke problemen' ook als belangrijkste reden voor hun voortijdige uitval. Dit geeft aan dat met name bij leerlingen die problemen op school of persoonlijke problemen hebben, spijbelen een vroeg signaal van voortijdige uitval kan zijn. Om dit vroege signaal te kunnen opvangen zouden spijbelaars extra moeten worden gemonitord en begeleid. Het is verstandig om daarbij extra aandacht te besteden aan spijbelaars die schoolgerelateerde oorzaken (lessen en/of opleiding zijn oninteressant te moeilijk of te makkelijk; uitval van lesuren; problemen in de klas, met leerlingen of leraren, gepest worden) of persoonlijke problemen (problematische thuissituatie; privéproblemen; zwangerschap) als spijbelreden noemen.

Aan de vsv'ers is gevraagd met wie zij, voordat zij de opleiding definitief verlieten, hebben gesproken over hun keuze om met de opleiding te stoppen. De vsv'ers waarbij de spijbelreden overeenkomt met de belangrijkste reden voor voortijdige uitval hebben iets vaker met 'iemand' gesproken over hun keuze om te stoppen dan de totale groep vsv'ers ( $83 \%$ ten opzichte van $81 \%$ ). Degenen met wie zij vaker spreken zijn met name ouders $(77 \%$ in plaats van $69 \%$ ) en vrienden (27\% in plaats van $20 \%$ ). Opvallend is dat de vsv'ers waarbij de spijbelreden overeenkomt met de belangrijkste reden voor voortijdige uitval, juist iets minder vaak over hun keuze hebben gesproken met mensen binnen de school (zie de onderste vier regels van tabel 3). Vsv'ers die aangeven nog nooit te hebben gespijbeld hebben daarentegen juist vaker met mensen binnen de school gepraat over de beslissing om voortijdig te stoppen. Binnen deze groep vsv'ers zijn er in ieder geval meer die met 'iemand' hebben gepraat $(86 \%)$. Het zou kunnen zijn dat de vsv'ers die nooit hebben gespijbeld in principe het liefst op school zouden 
Tabel 1

Redenen om te spijbelen, per opleidingsniveau (\%)

\begin{tabular}{|c|c|c|c|c|c|}
\hline \multirow[b]{2}{*}{ Spijbelreden } & \multicolumn{4}{|c|}{ Opleidingsniveau } & \multirow[b]{2}{*}{ Totaal } \\
\hline & AV0 & VMBO & MBO 1/2 & $\mathrm{MBO} 3 / 4$ & \\
\hline Schoolgerelateerde oorzaken & 42 & 32 & 43 & 58 & 49 \\
\hline (geestelijke) Gezondheidsklachten & 22 & 24 & 16 & 17 & 18 \\
\hline Persoonlijke problemen & 5 & 6 & 5 & 3 & 4 \\
\hline Arbeidsmarkt & 2 & 5 & 13 & 6 & 8 \\
\hline Anders & 31 & 34 & 22 & 16 & 22 \\
\hline Totaal & 100 & 100 & 100 & 100 & 100 \\
\hline
\end{tabular}

Tabel 2

Reden om te spijbelen, per belangrijkste reden voor voortijdige uitval (\%)

\begin{tabular}{|c|c|c|c|c|c|c|}
\hline \multirow[b]{2}{*}{ Spijbelreden } & \multicolumn{6}{|c|}{ Belangrijkste reden voortijdige uitval } \\
\hline & $\begin{array}{r}\text { Schoolgerelateerde } \\
\text { oorzaken }\end{array}$ & $\begin{array}{r}\text { (geestelijke) } \\
\text { Gezondheidsklachten }\end{array}$ & $\begin{array}{r}\text { Persoonlijke } \\
\text { problemen }\end{array}$ & Arbeidsmarkt & Anders & Totaal \\
\hline Schoolgerelateerde oorzaken & 60 & 10 & 6 & 14 & 11 & $100 \%$ \\
\hline (geestelijke) Gezondheidsklachten & 28 & 42 & 9 & 9 & 12 & $100 \%$ \\
\hline Persoonlijke problemen & 10 & 18 & 50 & 6 & 17 & $100 \%$ \\
\hline Arbeidsmarkt & 31 & 3 & 17 & 43 & 5 & $100 \%$ \\
\hline Anders & 38 & 17 & 16 & 14 & 16 & $100 \%$ \\
\hline
\end{tabular}

Tabel 3

Met wie heb je gesproken over je keuze om met de opleiding te stoppen? (\%)

\begin{tabular}{|c|c|c|c|}
\hline Met wie gesproken & Allen & Spijbelreden $=$ Vsvreden & Nooit gespijbeld \\
\hline Niemand & 19 & 17 & 14 \\
\hline lemand & 81 & 83 & 86 \\
\hline Ouders & 69 & 77 & 75 \\
\hline Broers/Zussen & 11 & 10 & 11 \\
\hline Vrienden & 20 & 27 & 16 \\
\hline Leraren & 18 & 19 & 20 \\
\hline Mentor & 34 & 31 & 37 \\
\hline Schoolleiding & 16 & 12 & 18 \\
\hline Zorg Advies Team & 12 & 11 & 15 \\
\hline
\end{tabular}

Tabel 4

Wie heeft volgens de vsv'ers geprobeerd hen te helpen om uitval te voorkomen? (\%)

\begin{tabular}{|c|c|c|c|c|}
\hline \multicolumn{5}{|c|}{ Wie heeft geprobeerd je te helpen, en met welk doel } \\
\hline & \multirow{4}{*}{$\begin{array}{l}\text { Niemand heeft } \\
\text { geprobeerd te helpen }\end{array}$} & \multicolumn{3}{|c|}{ lemand (school en/of andere instanties) heeft geprobeerd te helpen, namelijk: } \\
\hline & & School & Andere instanties & School / Andere instanties \\
\hline & & Diploma & Diploma & Andere opleiding \\
\hline & & $\%$ geholpen & $\%$ geholpen & \% geholpen \\
\hline Totaal & 45 & 38 & 21 & 27 \\
\hline \multicolumn{5}{|l|}{ Opleidingsniveau } \\
\hline AVO & 41 & 48 & 23 & 26 \\
\hline VMBO & 28 & 46 & 34 & 49 \\
\hline MBO $1 / 2$ & 51 & 34 & 19 & 23 \\
\hline $\mathrm{MBO} 3 / 4$ & 47 & 35 & 16 & 23 \\
\hline \multicolumn{5}{|l|}{ Vsv reden } \\
\hline Schoolgerelateerde oorzaken & 49 & 33 & 15 & 25 \\
\hline (geestelijke) Gezondheidsklachten & 32 & 49 & 29 & 34 \\
\hline Persoonlijke problemen & 42 & 36 & 32 & 27 \\
\hline Arbeidsmarkt & 43 & 42 & 21 & 25 \\
\hline Anders & 49 & 36 & 17 & 30 \\
\hline
\end{tabular}


willen blijven, waardoor ze minder spijbelen en meer hun best doen om met mensen te praten over hun keuze om voortijdig te stoppen.

Aan de vsv'ers is gevraagd of ze door hun school zijn gedwongen om te stoppen met hun opleiding, doordat de maximale verblijfsduur was bereikt (twee keer gezakt voor eindexamen) of omdat de leerling regels van de school had overtreden. De meeste vsv'ers $(83 \%)$ geven aan dat ze niet door de school zijn gedwongen om te stoppen met hun opleiding. Op het VMBO ligt dit percentage wat lager $(70 \%)$. Ook is de vsv'ers gevraagd of hun school en/of andere instanties pogingen hebben gedaan om hun voortijdige uitval te voorkomen, door ze te helpen alsnog een diploma te halen en/of door ze te helpen bij het overstappen naar een andere opleiding. Er konden meerdere antwoorden worden aangekruist. Tabel 4 geeft de resultaten van de antwoorden op deze vraag weer, uitgesplitst naar opleidingsniveau en belangrijkste reden voor voortijdige uitval.

In tabel 4 is te zien dat $45 \%$ van de vsv'ers aangeeft dat er niemand is geweest die heeft geprobeerd om hun voortijdige uitval te voorkomen. Dat wil zeggen dat de school noch een andere instantie volgens hen een poging heeft gedaan om te helpen bij het alsnog behalen van een diploma of het overstappen naar een andere studie. Van degenen die wel aangeven te zijn geholpen, geven de meesten aan dat ze zijn geholpen door de school bij het alsnog behalen van hun diploma $(38 \%)$.

Uitgesplitst naar opleidingsniveau is te zien dat met name vsv'ers afkomstig uit het $\mathrm{MBO}$ aangeven dat niemand een poging heeft gedaan hen te helpen ( $51 \% \mathrm{MBO}$ niveau $\mathrm{I} / 2,47 \% \mathrm{MBO}$ niveau 3/4). De vsv'ers afkomstig uit het $\mathrm{VMBO}$ geven relatief het minst vaak aan dat niemand een poging tot hulp heeft gedaan $(28 \%)$. Dit verschil tussen de (ervaren) pogingen tot het bieden van hulp tussen vsv'ers uit het MBO en vsv'ers uit het VMBO zou te maken kunnen hebben met de verschillen in organisatie en begeleiding tussen VMBO- en MBO-scholen. Op VMBOscholen krijgen leerlingen relatief veel begeleiding, terwijl op $\mathrm{MBO}$-scholen veel meer zelfstandigheid van de leerlingen wordt verwacht. Op alle opleidingsniveaus geeft ruim een derde tot de helft van de vsv'ers die aangeven dat er iemand geprobeerd heeft hen te helpen, aan dat (onder andere) hun school heeft geprobeerd te helpen bij het alsnog behalen van hun diploma. Van de vsv'ers afkomstig uit het VMBO geeft $49 \%$ aan dat (onder andere) hun school en/ of andere instanties pogingen hebben gedaan om te helpen bij het overstappen naar een andere opleiding. Het is waarschijnlijk dat dit hoge percentage ermee te maken heeft dat VMBO-leerlingen die voortijdig (dreigen te) stoppen met hun opleiding, op het $\mathrm{MBO}$ worden aangenomen zonder in het bezit te zijn van een VMBO-diploma.

Uitgesplitst naar de belangrijkste reden voor voortijdige uitval is te zien dat met name de vsv'ers die zijn gestopt vanwege schoolgerelateerde oorzaken aangeven dat niemand heeft geprobeerd hen te helpen (49\%). De vsv'ers die zijn gestopt vanwege (geestelijke) gezondheidsklachten geven relatief het minst vaak aan dat niemand geprobeerd heeft te helpen $(32 \%)$. Bij alle redenen voor voortijdige uitval geven de meeste vsv'ers die aangeven dat er iemand geprobeerd heeft hen te helpen, aan dat (onder andere) hun school heeft geprobeerd te helpen bij het alsnog behalen van hun diploma.

Bij deze resultaten is het belangrijk om op te merken dat het hier niet hoeft te gaan om de daadwerkelijke hulppogingen van scholen en andere instanties (of het gebrek daaraan). Het is mogelijk dat er pogingen zijn ondernomen om de voortijdige uitval te voorkomen, maar dat de vsv'ers dat niet als zodanig hebben ervaren. Ook is het mogelijk dat de leerling destijds niet open stond voor hulp waardoor de pogingen (uiteindelijk) zijn gestaakt. Desondanks blijft het opmerkelijk dat er dusdanig veel vsv'ers zijn die aangeven (het idee te hebben) dat ze door niemand zijn geholpen.

\subsection{Pesten}

Aan zowel gediplomeerden als vsv'ers is gevraagd of ze wel eens zijn gepest, en zo ja om welke reden zij zijn gepest. Figuur 3 geeft uitgesplitst naar opleidingsniveau weer hoeveel vsv'ers en gediplomeerden relatief gezien zijn gepest.

\section{Figuur 3}

Gepest zijn: gediplomeerden vergeleken met vsv'ers

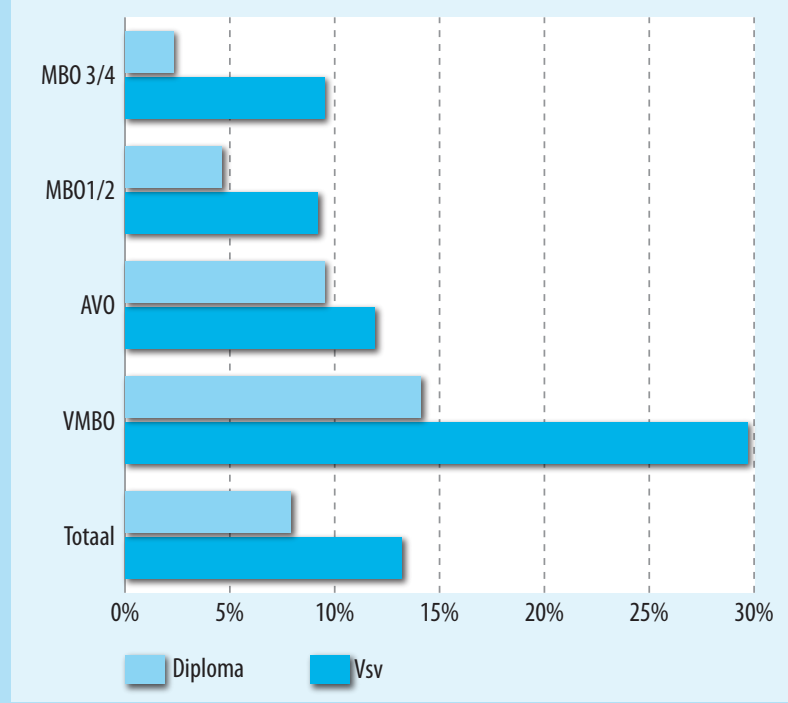

Uit figuur 3 blijkt dat vsv'ers in totaal wat vaker aangeven te zijn gepest dan gediplomeerden ( $13 \%$ tegenover $8 \%$ ). Dit geldt voor vsv'ers en gediplomeerden van alle opleidingsniveaus. Vooral in het VMBO zijn de verschillen tussen gediplomeerden en vsv'ers groot: $30 \%$ van de vsv'ers uit het VMBO geeft aan te zijn gepest, tegenover $14 \%$ van de gediplomeerde VMBO-ers. Binnen de groep 'gediplomeerde $\mathrm{MBO}$-ers niveau $3 / 4$ ' is vrijwel niemand gepest (2\%).

Wanneer een leerling (vsv'er of gediplomeerde) is gepest, is dat meestal vanwege het uiterlijk ( $5 \%$ van de vsv'ers, $4 \%$ van de gediplomeerden) of vanwege een ziekte of handicap ( $3 \%$ van de vsv'ers, I\% van de gediplomeerden). Het geloof of de seksuele geaardheid wordt vrijwel nooit opgegeven als een oorzaak van het pesten ( $0,7 \%$ van de vsv'ers, $0,4 \%$ van de gediplomeerden). Vergeleken met VMBO-gediplomeerden 
worden vsv'ers uit het VMBO met name vaker gepest vanwege hun uiterlijk (I2\% tegenover $7 \%$ ) en hun ziekte of handicap ( $9 \%$ tegenover $\mathrm{I} \%$ ).

\section{Huidige bezigheid}

Van de vsv'ers is het merendeel na ongeveer anderhalf jaar aan het werk $(37,5 \%)$ of weer aan het studeren $(35,4 \%)$ (zie tabel 5). Dit blijkt als gekeken wordt naar de antwoorden op de vraag 'Wat doe je nu' uit de vragenlijst. Hoewel dit strikt genomen nog niet betekent dat $37,5 \%$ tot de werkzame beroepsbevolking behoort, geeft deze vraag en goede indicatie van de belangrijkste bezigheid van de respondenten. Evenals bij de gediplomeerde uitstromers stromen de vsv'ers uit het HAVO/VWO en VMBO met name door naar het onderwijs; rond de $70 \%$ van hen is op enquêtemoment weer met een studie bezig. Vsv'ers afkomstig uit het MBO zijn duidelijk actiever op de arbeidsmarkt. Ondanks dat ook zij geen startkwalificatie hebben geeft zo'n $49 \%$ van de niveau I $/ 2$ en bijna $47 \%$ van de niveau $3 / 4$ schoolverlaters aan op enquêtemoment aan het werk te zijn. Opvallend is verder dat onder de $\mathrm{MBO}$ niveau I/2 een relatief grote groep jongeren aangeeft niet aan het werk en niet aan het studeren te zijn.

Dat er een verband is tussen de redenen van uitval en de persoonlijke situatie van de respondenten op enquêtemoment blijkt uit tabel 6. De vsv'ers die vanwege gezondheidsklachten, persoonlijke problemen of zorgtaken met hun studie gestopt zijn geven het vaakst aan op enquêtemoment niet werkzaam of studerend te zijn. Jongeren die vanwege een voorkeur voor de arbeidsmarkt zijn gestopt, zijn voor het merendeel werkend. Uit de tabel blijkt echter ook dat niet iedereen die vanwege een verkeerde studiekeuze wat richting of niveau betreft met een beter passende studie een nieuwe start in het onderwijs maakt. Grote delen van deze groepen geven aan dat hun bezigheid op enquêtemoment 'werk' is.

Van de totale groep vsv'ers biedt iets minder dan $40 \%$ zich aan op de arbeidsmarkt. Gemiddeld is één op de vijf werkloos, onder de vsv'ers van het VMBO die zich op de arbeidsmarkt aanbieden ligt dit zelfs rond de $36 \%$. Ook de kwaliteit van het gevonden werk laat te wensen over. In tabel 7 staan enkele belangrijke arbeidsmarktindicatoren weergegeven voor zowel de vsv'ers als de gediplomeerden die wel een startkwalificatie op MBO niveau 2 hebben behaald. Over de gehele groep vsv'ers heeft meer dan de helft een tijdelijk

Tabel 5

Belangrijkste bezigheid op het moment van enquêteren (\%)

\begin{tabular}{|c|c|c|c|c|c|}
\hline & AVO & VMBO & MBO 1/2 & $\mathrm{MBO} 3 / 4$ & Totaal \\
\hline Werk & 12 & 9 & 49 & 47 & 38 \\
\hline Studie & 70 & 73 & 15 & 27 & 35 \\
\hline Combinatie werk/leren & 6 & 4 & 4 & 7 & 5 \\
\hline Anders & 12 & 15 & 32 & 19 & 22 \\
\hline Totaal & $100 \%$ & $100 \%$ & $100 \%$ & $100 \%$ & $100 \%$ \\
\hline
\end{tabular}

Tabel 6

Belangrijkste bezigheid naar belangrijkste reden voortijdige uitval (\%)

\begin{tabular}{|c|c|c|c|c|c|c|c|c|c|}
\hline & $\begin{array}{r}\text { School- } \\
\text { gerelateerde } \\
\text { oorzaken }\end{array}$ & $\begin{array}{r}\text { (geestelijke) } \\
\text { Gezondheids- } \\
\text { klachten }\end{array}$ & $\begin{array}{r}\text { Persoonlijke } \\
\text { problemen }\end{array}$ & $\begin{array}{r}\text { Verkeerde } \\
\text { opleidings- } \\
\text { keuze }\end{array}$ & $\begin{array}{l}\text { Opleiding } \\
\text { te zwaar }\end{array}$ & Arbeidsmarkt & Zorgtaken & Verhuisd & Anders \\
\hline Werk & 43 & 22 & 28 & 34 & 43 & 68 & 33 & 14 & 37 \\
\hline Studie & 37 & 36 & 34 & 47 & 38 & 11 & 20 & 66 & 39 \\
\hline Combinatie werken-leren & 5 & 5 & 3 & 8 & 5 & 5 & 0 & 0 & 4 \\
\hline Anders, $\mathrm{nl}$. & 15 & 37 & 35 & 11 & 15 & 16 & 47 & 20 & 21 \\
\hline Totaal & $100 \%$ & $100 \%$ & $100 \%$ & $100 \%$ & $100 \%$ & $100 \%$ & $100 \%$ & $100 \%$ & $100 \%$ \\
\hline
\end{tabular}

Tabel 7

Werkloosheid en kenmerken huidige baan

\begin{tabular}{|c|c|c|c|c|c|c|}
\hline & \multicolumn{4}{|c|}{ Vsv'ers } & \multirow{3}{*}{$\begin{array}{r}\text { Totaal } \\
\%\end{array}$} & \multirow{3}{*}{$\begin{array}{r}\mathrm{MBO} 2 \\
\text { gediplomeerden } \\
\%\end{array}$} \\
\hline & AVO & VMBO & MBO $1 / 2$ & $\mathrm{MBO} 3 / 4$ & & \\
\hline & $\%$ & $\%$ & $\%$ & $\%$ & & \\
\hline Werkloosheid & 25 & 36 & 26 & 13 & 20 & 8 \\
\hline Tijdelijke aanstelling & 41 & 64 & 60 & 54 & 56 & 38 \\
\hline Loondienst & 85 & 56 & 74 & 76 & 75 & 64 \\
\hline \multirow[t]{2}{*}{ (Zeer) tevreden met functie } & 63 & 62 & 55 & 54 & 55 & 65 \\
\hline & $€$ & $€$ & $€$ & $€$ & $€$ & $€$ \\
\hline Uurloon & 7,48 & 5,25 & 7,41 & 7,31 & 7,26 & 9,78 \\
\hline Maandloon & 872 & 657 & 1.072 & 969 & 991 & 1.412 \\
\hline
\end{tabular}


dienstverband en is bijna $55 \%$ tevreden tot zeer tevreden met de functie. Onder de gediplomeerden ligt het percentage met een tijdelijk dienstverband aanzienlijk lager en geeft $65 \%$ aan tevreden tot zeer tevreden te zijn met de huidige functie. De vsv'ers zijn iets vaker in loondienst werkzaam dan de schoolverlaters met wel een startkwalificatie. Het grote verschil tussen het betreden van de arbeidsmarkt met of zonder een startkwalificatie komt met name tot uitdrukking in de beloning: de $\mathrm{MBO}$ niveau 2 gediplomeerden verdienen duidelijk meer dan de vsv'ers zonder startkwalificatie. Zo heeft de eerst groep een uurloon van $€ 9,78$ terwijl de tweede groep slechts $€ 7,26$ per uur verdient.

Figuur 4 toont dat voor een groot deel van de functies geldt dat het ongeschoold werk is, dat wil zeggen dat het gaat om een baan waar geen diploma voor vereist is. Dit is met name het geval bij de VMBO uitvallers. Zoals uit tabel 7 al blijkt doen, ook als het gaat om het vereist niveau van de gevonden banen, de AVO uitvallers het relatief gezien het beste.

Figuur 4

Vereist opleidingsniveau huidige baan

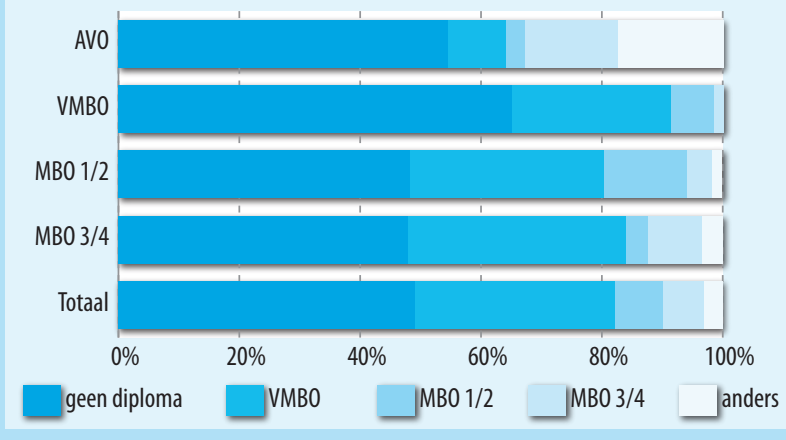

Figuur 5

Percentage vsv'ers dat niet actief is op de arbeidsmarkt en tevens niet studerend, naar belangrijkste reden voor verlaten opleiding

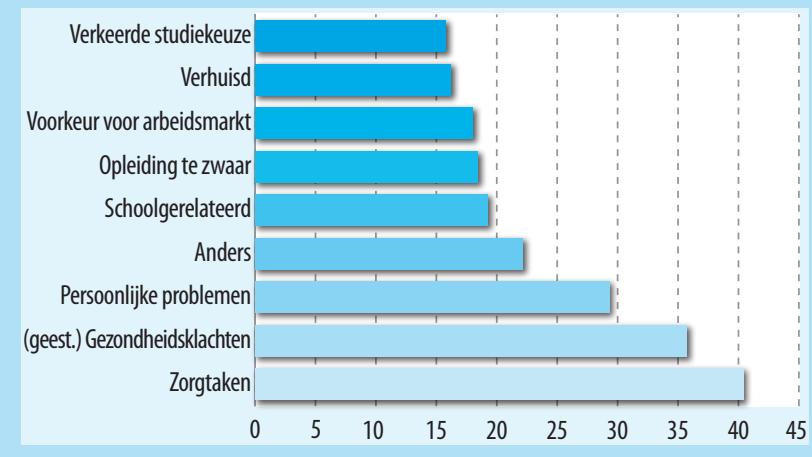

Dat er verschillen zijn in het succes van vsv'ers en gediplomeerden op de arbeidsmarkt is te verwachten. Uit tabel 8 blijkt tevens dat ook de groep inactieven onder de vsv'ers relatief veel groter is dan onder de gediplomeerden. Van de vsv'ers is zo'n $64 \%$ werkzaam of bezig met een studie, bijna $8 \%$ is op zoek naar werk en een groep van een kleine $28 \%$ heeft geen werk of studie en is op zich ook niet op zoek naar werk. Onder de vergelijkbare gediplomeerden ligt dit percentage op nog geen $9 \%$. Wanneer gekeken wordt naar de reden van uitval (zie tabel 8) blijkt dat met name onder de personen die uitvallen vanwege gezondheids - of persoonlijke problemen en onder de mensen die vanwege zorgtaken met hun opleiding gestopt zijn er een aanzienlijk deel is dat niet actief op de arbeidsmarkt of studerend is. Leerlingen die waren gestopt vanwege een verkeerde studiekeuze stromen zoals verwacht doorgaans weer terug naar het onderwijs.

\section{Toekomstplannen en spijt achteraf}

Een belangrijke vraag is in hoeverre de vsv'ers definitief niet terug naar school keren. In tabel 9 staat wat de toekomstplannen van de respondenten met betrekking tot hun onderwijsloopbaan zijn. Uit de tabel wordt duidelijk dat er nogal een verschil is tussen de schoolverlaters van het AVO en VMBO enerzijds en de voortijdige $\mathrm{MBO}$ uitstroom anderzijds. Slechts een klein deel van de AVO $(5,2 \%)$ en de VMBO $(9,8 \%)$ afvallers is niet van plan om in de toekomst nog terug te keren naar het onderwijs. Onder de vsv'ers uit het $\mathrm{MBO}$ is deze groep aanzienlijk groter. Ook geeft een kleiner deel van deze laatste groep aan bezig te zijn met een opleiding of alweer ingeschreven te staan voor een nieuwe opleiding. Dit alles zal er mee te maken hebben dat de oud MBO-leerlingen ondanks het gebrek aan een startkwalificatie toch meer op de arbeidsmarkt gericht zijn dan de vsv'ers van het $\mathrm{AVO}$ en VMBO.

Zoals uit de tabel blijkt is de twijfel omtrent de studiekeuze een belangrijke reden waarom een deel van de respondenten nog niet aan een nieuwe studie begonnen is. Daarnaast spelen de kosten een belangrijke rol; voor bijna een kwart van de respondenten die niet bezig zijn met een nieuwe studie en ook nog niet ingeschreven staan zijn de studiekosten een reden die hen tegenhoudt met een nieuwe studie te beginnen. Een andere reden die vaak genoemd wordt is 'persoonlijke omstandigheden'. Wanneer gekeken wordt naar factoren die ertoe zouden bijdragen dat men wel een studie zou willen volgen blijkt dat deze van velerlei aard zijn. Een bijdrage in de studiekosten is één van deze factoren, daarnaast wordt de mogelijkheid voor het combineren van de studie met het werk ook als een belangrijke factor gezien. Meer begeleiding bij zowel de studiekeuze als de studie zelf kan eveneens bijdragen tot een hogere onderwijsdeelname onder de vsv'ers.

Figuur 6 laat zien in hoeverre de vsv'ers achteraf bezien spijt hebben van hun beslissing destijds om te stoppen met hun opleiding. Opvallend is dat slechts een klein deel van de vsv'ers, voor de gehele groep I2,6\%, aangeeft spijt te hebben van hun beslissing in die zin dat ze nu niet weer dezelfde beslissing zouden nemen. Deze groep is relatief gezien het grootst bij de $\mathrm{MBO}$ I/2 uitvallers. Ongeveer $35 \%$ geeft aan weliswaar spijt te hebben maar door omstandigheden geen andere keuze gehad te hebben destijds hetgeen impliceert dat ze deze zelfde keuze nu weer zouden (moeten) maken. Ten opzichte van het vorige meetjaar heeft er een verschuiving plaatsgevonden. De groep die weliswaar spijt heeft maar niet anders kon is met zo'n 8\%-punten gestegen terwijl de andere beide groepen met ieder ongeveer $4 \%$-punten zijn 
afgenomen. Dit betekent dat de groep die echt spijt heeft weliswaar gedaald is maar dat de groep die helemaal geen spijt heeft ook kleiner geworden is en dat er relatief gezien meer jongeren 'gedwongen' waren om te stoppen.

Figuur 6

Spijt met keuze om te stoppen naar opleidingsniveau

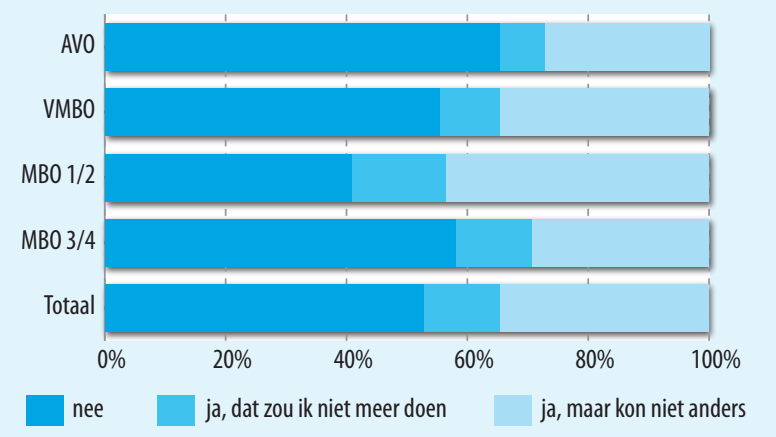

In hoeverre de schoolverlaters spijt hebben van hun keuze om te stoppen met de opleiding die ze aan het volgen waren hangt sterk af van de reden waarom ze gestopt zijn. Men heeft het minst vaak spijt indien de belangrijkste reden te maken had met een verkeerde studiekeuze (zie tabel ro). Zo is ook de belangrijkste reden vaak de verklaring voor het hoge percentage respondenten die destijds min of meer onvrijwillig met hun studie gestopt zijn. Iets meer dan $40 \%$ van de schoolverlaters die vanwege zorgtaken gestopt zijn geeft aan dat jammer te vinden maar dat er geen andere keuze was, bij de mensen die gestopt zijn vanwege gezondheidsklachten is dit eveneens een grote groep (bijna 36\%).

Deze cijfers kunnen ook een verklaring zijn voor de relatieve toename van groep die onvrijwillig gestopt is ten opzichte van het vorige meetjaar. Gezondheidsklachten en zorgtaken zijn redenen die moeilijk door overheidsinstanties en scholen beïnvloed kunnen worden. Als scholen door een betere hulp bij de studiekeuze en betere begeleiding het aantal vsv'ers in positieve zin beïnvloeden zal relatief gezien de groep die vanwege gezondheidsklachten en zorgtaken afhaakt steeds groter worden ondanks een wellicht steeds efficiënter beleid.

Tabel 8

Aandeel van schoolverlaters dat niet actief is op de arbeidsmarkt en tevens niet studerend naar verlaten opleidingsniveau (\%)

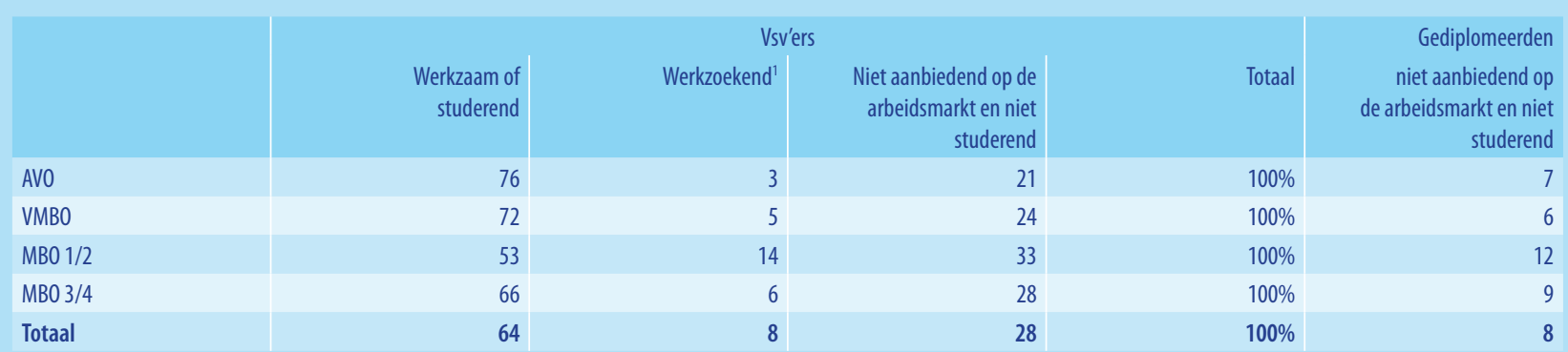

'In tegenstelling tot het werkloosheidspercentage is dit percentage gebaseerd op de totale groep vsv'ers en niet op alleen de groep die zich aanbiedt op de arbeidsmarkt en derhalve niet gelijk aan het werkloosheidspercentage.

Tabel 9

Toekomstplannen voor verder studeren (\%)

\begin{tabular}{|c|c|c|c|c|c|}
\hline & $\begin{array}{l}\text { Is ingeschreven } \\
\text { bij een opleiding }\end{array}$ & $\begin{array}{r}\text { Wel van plan maar weet } \\
\text { nog niet welke opleiding } \\
\text { en wanneer }\end{array}$ & $\begin{array}{r}\text { Is bezig } \\
\text { met opleiding }\end{array}$ & $\begin{array}{r}\text { Niet van plan } \\
\text { verder te studeren }\end{array}$ & Totaal \\
\hline AVO & 20 & 34 & 42 & 5 & $100 \%$ \\
\hline VMBO & 13 & 41 & 37 & 10 & $100 \%$ \\
\hline MBO 1/2 & 11 & 54 & 14 & 22 & $100 \%$ \\
\hline MBO $3 / 4$ & 8 & 48 & 28 & 16 & $100 \%$ \\
\hline Totaal & 11 & 47 & 26 & 16 & $100 \%$ \\
\hline
\end{tabular}

Tabel 10

Spijt met keuze om te stoppen naar belangrijkste reden stoppen met opleiding (\%)

\begin{tabular}{|c|c|c|c|c|}
\hline & Nee & Ja, dat zou ik niet meer doen & Ja, maar kon niet anders & Totaal \\
\hline Schoolgerelateerd & 75 & 6 & 19 & 100 \\
\hline (geest.) gezondheidsklachten & 53 & 11 & 36 & 100 \\
\hline Persoonlijke problemen & 57 & 14 & 29 & 100 \\
\hline Verkeerde studiekeuze & 79 & 5 & 16 & 100 \\
\hline Opleiding te zwaar & 76 & 6 & 18 & 100 \\
\hline Voorkeur voor arbeidsmarkt & 74 & 8 & 18 & 100 \\
\hline Zorgtaken & 44 & 16 & 40 & 100 \\
\hline Verhuisd & 74 & 10 & 16 & 100 \\
\hline Anders & 70 & 8 & 22 & 100 \\
\hline
\end{tabular}




\section{Conclusies}

In dit factsheet is kort ingegaan op de redenen voor uitval, de situatie op school, de huidige bezigheid en de toekomstplannen van ongediplomeerde voortijdige schoolverlaters. Enkele belangrijke bevindingen zijn:

- schoolrelateerde oorzaken (geestelijke) gezondheidsklachten zijn de belangrijkste redenen voor voortijdige schooluitval;

- met name bij leerlingen die spijbelen vanwege problemen op school of vanwege persoonlijke problemen kan spijbelen een vroeg signaal van voortijdige uitval zijn;

- vsv'ers geven iets vaker dan gediplomeerde aan gepest te zijn op school;

- zo'n $13 \%$ van de vsv'ers geeft aan achteraf spijt te hebben van hun beslissing om te stoppen met de opleiding die ze aan het volgen waren. 


\section{Bijlagen}

Tabel B1

Achtergrondkenmerken respondenten (\%)

\begin{tabular}{|c|c|c|c|c|c|}
\hline & AVO & VMBO & MBO $1 / 2$ & $\mathrm{MBO} 3 / 4$ & Totaal \\
\hline \multicolumn{6}{|l|}{ Geslacht } \\
\hline $\operatorname{man}$ & 49 & 60 & 52 & 40 & 49 \\
\hline vrouw & 51 & 41 & 48 & 60 & 52 \\
\hline \multicolumn{6}{|l|}{ Etniciteit } \\
\hline Westerse allochtoon & 12 & 8 & 6 & 8 & 8 \\
\hline Niet-westerse allochtoon & 10 & 18 & 20 & 14 & 16 \\
\hline Autochtoon & 78 & 74 & 73 & 78 & 76 \\
\hline \multicolumn{6}{|l|}{ Gezinssamenstelling } \\
\hline Tweeoudergezin & 64 & 54 & 44 & 48 & 49 \\
\hline Éénouder gezin & 21 & 30 & 26 & 21 & 24 \\
\hline lk woon zelfstandig & 9 & 3 & 14 & 21 & 14 \\
\hline Anders, namelijk & 5 & 14 & 16 & 11 & 13 \\
\hline \multicolumn{6}{|l|}{ Spreektaal ouders } \\
\hline (bijna) altijd Nederlands & 78 & 70 & 62 & 71 & 69 \\
\hline Nederlands en een andere taal & 9 & 13 & 13 & 12 & 12 \\
\hline (bijna) altijd een andere taal & 2 & 4 & 5 & 2 & 3 \\
\hline Niet van toepassing & 11 & 13 & 20 & 14 & 16 \\
\hline \multicolumn{6}{|l|}{ Opleidingsniveau ouders } \\
\hline \multicolumn{6}{|l|}{ Vader } \\
\hline Basisonderwijs & 5 & 7 & 12 & 10 & 9 \\
\hline Lager beroepsonderwijs & 12 & 27 & 35 & 33 & 30 \\
\hline Voortgezet onderwijs & 8 & 9 & 8 & 7 & 8 \\
\hline Middelbaar beroepsonderwijs & 18 & 26 & 29 & 24 & 25 \\
\hline Hoger onderwijs & 57 & 32 & 16 & 27 & 28 \\
\hline \multicolumn{6}{|l|}{ Moeder } \\
\hline Basisonderwijs & 2 & 8 & 13 & 10 & 10 \\
\hline Lager beroepsonderwijs & 16 & 24 & 32 & 38 & 31 \\
\hline Voortgezet onderwijs & 11 & 10 & 11 & 7 & 9 \\
\hline Middelbaar beroepsonderwijs & 27 & 33 & 31 & 27 & 29 \\
\hline Hoger onderwijs & 43 & 25 & 12 & 18 & 20 \\
\hline \multicolumn{6}{|l|}{ Kinderen } \\
\hline Ja & 1 & 2 & 14 & 7 & 8 \\
\hline Nee & 99 & 98 & 86 & 94 & 93 \\
\hline
\end{tabular}


Tabel B2

Belangrijkste reden voortijdige uitval, incl. indeling naar hoofdcategorieën* (\%)

\begin{tabular}{|c|c|c|c|c|c|}
\hline & & AVO & VMBO & MBO $1 / 2$ & $\mathrm{MBO} 3 / 4$ \\
\hline \multirow[t]{13}{*}{ Schoolgerelateerde oorzaken } & problemen op de leerwerkplek/stage (bijv. ontslag) & 1 & 0 & 9 & 5 \\
\hline & ik had problemen met de leraren/schoolleiding & 6 & 8 & 5 & 3 \\
\hline & ik had problemen met andere leerlingen & 0 & 3 & 0 & 1 \\
\hline & ik voelde me niet veilig op de school & 1 & 4 & 0 & 0 \\
\hline & de opleiding was slecht georganiseerd & 8 & 4 & 6 & 10 \\
\hline & (ik kreeg onvoldoende begeleiding) & 2 & 1 & 1 & 0 \\
\hline & (kwaliteit onderwijs was slecht) & 0 & 0 & 0 & 0 \\
\hline & (ik werd gepest) & 0 & 1 & 0 & 0 \\
\hline & ik wilde van opleiding wisselen & 7 & 7 & 5 & 4 \\
\hline & de opleiding was inhoudelijk (toch) niet wat ik wilde & 2 & 2 & 10 & 18 \\
\hline & ik vond het niveau van de opleiding te laag & 0 & 3 & 2 & 4 \\
\hline & (indicatie speciaal onderwijs) & 1 & 2 & 0 & 0 \\
\hline & de opleiding was te moeilijk en/of gezakt voor het eindexamen & 17 & 7 & 6 & 3 \\
\hline Subtotaal & & 45 & 40 & 44 & 48 \\
\hline \multirow[t]{4}{*}{ (Geestelijke) gezondheidsklachten } & ziekte & 9 & 6 & 6 & 7 \\
\hline & verslavingsproblemen & 2 & 2 & 4 & 1 \\
\hline & psychische problemen & 13 & 19 & 5 & 8 \\
\hline & (handicap) & 0 & 0 & 1 & 0 \\
\hline Subtotaal & & 24 & 27 & 15 & 16 \\
\hline
\end{tabular}

Persoonlijke problemen

Relatieproblemen/gezinsproblemen (bijv. scheiding van ouders)

in aanraking komen met politie/justitie

(financiële redenen)

zwangerschap

school in combinatie met zorg voor kinderen, en/of familie was te zwaar

Subtotaal

ik wilde liever gaan werken

ik had een inkomen nodig en ben daarom gaan werken

Subtotaal

Anders

ik ging verhuizen

anders

(door school gedwongen te stoppen)

Subtotaal

Totaal

100

100

\begin{tabular}{|r|r|r|}
\hline 6 & 4 & 5 \\
\hline 2 & 1 & 1 \\
\hline 1 & 1 & 1 \\
\hline 1 & 4 & 3 \\
\hline 1 & 0 & 1 \\
\hline
\end{tabular}

* Er is een aantal respondenten dat als belangrijkste reden voor voortijdige uitval heeft opgegeven 'een andere belangrijke reden, namelijk'. De antwoorden die deze respondenten hebben gegeven zijn voor zover mogelijk ingedeeld in bestaande en nieuwe categorieën. Deze nieuwe categorieën zijn in de tabel herkenbaar gemaakt door middel van haakjes '(...)'. 
Tabel B3

Spijbelredenen incl. indeling naar hoofdcategorieën* $(\%)$

\begin{tabular}{|c|c|c|c|c|c|c|}
\hline & & AVO & VMBO & MBO 1/2 & $\mathrm{MBO} 3 / 4$ & Totaal \\
\hline \multirow[t]{10}{*}{ Schoolgerelateerde oorzaken } & (Pesten) & 0 & 3 & 0 & 2 & 1 \\
\hline & (School, overige) & 6 & 4 & 2 & 3 & 3 \\
\hline & (lk was bang) & 0 & 2 & 0 & 0 & 0 \\
\hline & (Problemen in de klas) & 0 & 1 & 1 & 2 & 1 \\
\hline & (Lesuren, uitval) & 0 & 2 & 1 & 3 & 2 \\
\hline & (Problemen met leraren) & 2 & 3 & 1 & 1 & 1 \\
\hline & Sommige lessen oninteressant & 25 & 10 & 18 & 27 & 22 \\
\hline & Hele opleiding oninteressant & 8 & 7 & 17 & 19 & 16 \\
\hline & (Lessen te makkelijk) & 1 & 1 & 2 & 1 & 1 \\
\hline & (Lessen te moeilijk) & 0 & 0 & 1 & 1 & 1 \\
\hline Subtotaal & & 42 & 32 & 43 & 58 & 49 \\
\hline \multirow[t]{4}{*}{ (Geestelijke) gezondheidsklachten } & Te moe & 15 & 16 & 11 & 12 & 12 \\
\hline & (Ziekte) & 1 & 1 & 1 & 2 & 2 \\
\hline & (Psychische problemen) & 5 & 7 & 2 & 3 & 3 \\
\hline & (Verslaving) & 1 & 0 & 2 & 0 & 1 \\
\hline Subtotaal & & 22 & 24 & 16 & 17 & 18 \\
\hline \multirow[t]{3}{*}{ Persoonlijke problemen } & (Thuissituatie) & 5 & 4 & 3 & 2 & 3 \\
\hline & (Privé) & 0 & 1 & 2 & 2 & 1 \\
\hline & (Zwanger) & 0 & 0 & 1 & 0 & 1 \\
\hline Subtotaal & & 5 & 6 & 5 & 3 & 4 \\
\hline Arbeidsmarkt & Liever werken om geld te verdienen & 2 & 5 & 13 & 6 & 8 \\
\hline Subtotaal & & 2 & 5 & 13 & 6 & 8 \\
\hline \multirow[t]{4}{*}{ Anders } & Liever tijd met vrienden doorbrengen & 16 & 21 & 12 & 7 & 11 \\
\hline & Liever sporten & 3 & 1 & 0 & 1 & 1 \\
\hline & Anders & 10 & 11 & 9 & 7 & 9 \\
\hline & (Meerdere redenen) & 2 & 1 & 1 & 1 & 1 \\
\hline Subtotaal & & 31 & 34 & 22 & 16 & 22 \\
\hline Totaal & & 100 & 100 & 100 & 100 & 100 \\
\hline
\end{tabular}

* Er is een aantal respondenten dat als belangrijkste reden voor spijbelen heeft opgegeven 'anders, namelijk'. De antwoorden die deze respondenten hebben gegeven zijn voor zover mogelijk ingedeeld in bestaande en nieuwe categorieën. Deze nieuwe categorieën zijn in de tabel herkenbaar gemaakt door middel van haakjes '(...)'. 


\section{Colofon}

(C) Researchcentrum voor Onderwijs en Arbeidsmarkt (ROA). Niets uit deze uitgave mag op enige manier worden verveelvoudigd zonder voorafgaande schriftelijke toestemming van de directeur van het ROA.

\section{Researchcentrum voor Onderwijs en Arbeidsmarkt}

Maastricht University

School of Business and Economics

secretary-roa-sbe@maastrichtuniversity.nl

www.roa.nl

\section{Vormgeving}

ROA secretariaat, Maastricht

juni 2012 
Researchcentrum voor Onderwijs en Arbeidsmarkt

Postbus 616

6200 MD Maastricht

$\mathrm{T}+31433883647$

F +31 433884914

secretary-roa-sbe@maastrichtuniversity.nl

www.roa.nl

Maastricht University

School of Business and Economics 